\title{
『順天堂医学』投稿規程 (1997年7月1日より実施)
}

1. 原稿本文は日本語を原則とする.

2. 原著論文は, 原則として順天堂医学会会員からの投稿 のみとし，別に定める執筆ガイドラインによって刷上 がり10頁以内となるように整える. なお，4頁までを 無料とし，5頁以上は実費揭載料を徵収する。

3.1) 症例, 実験方法などの報告あるいは速報は, 刷上がり 4頁以内に整える.なお，2頁までを無料とし，3頁以 上は実費掲載料を徵収する.

2) カンファランス症例報告は刷上がりを 3 頁とし，2頁 までを無料とする。（題名・著者名・所属など $1 / 3$, 要約 $1 / 3$, 本文 1 頁 (6枚以内), 写真及び図表 1 頁, 文献 $1 / 3$ 頁)

4. 総説は長さに制限を設けないが，刷上がり4頁までを 無料とし，5頁以上は実費掲載料を徵収する。

5. 図表の製版代は著者負担とする.

6. 別刷は30部までを無料とする．超過頁のある場合は 実費掲載料の納入時に別刷代を請求し, 納入後別刷が 出来しだい配付する.

7. 原稿（プロムナードなどを除く）には，表題・所属 名・著者名，5個以内のキーワードを日本語及び英語 で記載し，さらに原著には 500 語以内の英文サマリー と 800 字以内の日本語抄録をつける.

8. 投稿論文には, 副本 (コピー) 2 部を添付する.

9. 投稿論文の採用 /不採用, 掲載順序は, 編集委員が決 定する.

10. 原稿の送付先は，下記の通りである. 干113-8421 東京都文京区本郷 2 丁目1番1号

\section{順天堂大学内 順天堂医学編集室}

§03-5802-1007(ダイヤルイン)内線 3116

11. 原稿の書き方の原則は下記の通りとするが，原著につ いては別に定めた『原著論文投稿ガイドライン』に従 うこと.

a. 原稿はA4版横書き 400 字詰原稿用紙を用い黒 / 青 のインク又はボールペン書きとし（ワードプロセッ サーを用いる場合はA4用紙で $20 \times 20$ 字に印字す る）本誌専用の表紙を付す. ステープルによって， 緅じる必要はない。

b. 原稿は当用漢字新仮名づかい平仮名まじりで記述する.

c. 外国語は原語で記述する時は活字体 (原則として夕 イプライター使用）を用い，日本語の場合は片仮名 を用いる。

d. 数字は算用数字を用い, 単位は原則としてCGS 単
位による. 単位略語の後に点を付けない $(\mathrm{g}$. でなく $\mathrm{g})$. 特殊な単位を用いる場合は必ず説明をつける.

e. 略語を用いる場合，ごく一般的なものを除き，最初 の記述（文中で最初に出てきたところ）で必ずspell outする。

$\mathrm{f}$ ．図及び表は本文とは別にし，図-1，表-2などの番 号及び表題・説明を付ける. 本文中にはこれらの図 あるいは表を挿入すべき場所を原稿右欄外に赤字で その位置を指定する，なお，図の原稿はそのまま製 版できるものであることを原則とする（写真は図と して取り扱う).

g. 文献は引用順とし，文献リストの番号を片括弧に入 れて本文中に付す (例：橋本ら")によれば……. 文献が共著の場合は，3名まではすべて記述し，4 名以上は……他，あるいは……et al. と記述する. 【文献記載例】〔1)，2）は雑誌の例，3）,4）は単行本 の例]

1）河合祥雄：心筋梗塞の病理の今日的問題点. 順天堂医 学, $1994 ; 39: 427 \sim 42$.

2) Yon WC, Blot WJ, Li JY.: Precancerous gastric lesion in a population at high risk of stomach cancer. Cancer Res., 1993 ; 53 : 1317 21.

3) Matsumoto A, Arai Y. : Hypothalamus. In : Matsumoto A, Ishii S, eds. Atlas of Endocrine Organs. Berlin : Springer-Verlag, 1992:25 38.

4) 平松啓一：ブドウ球菌., 松本慶蔵編. 新・病原菌の今 日的意味. 大阪；医薬ジャーナル社, $1992 ： 135 \sim 42$.

丸英文サマリー及び日本語抄録の書き方の改訂

下記の項目ごとに段落を分けて記述する.

1. Objective (目的)

2. Materials (Patients or Participants) (対象)

3. Methods (Interventions) (方法)

4. Measurement and Results (結果)

5. Conclusions (結論)

〔1と2の間にDesign（研究様式）とSetting（環境の設 定）を加えることも可.]

〔主に臨床研究を念頭に置いた項目なので，論文内容に 該当していないものがある時は, 編集委員会と協議して 決めることとする.」

・これに伴い，英文 500 語以内，和文 800 字以内とする.

（ネ新しく改訂した部分）

\section{原 稿 募 集}

会員諸氏に,より親しみやすく・楽しく・読みやすい雑誌とするために〈医学プロムナード〉に加えて〈診療ノート〉 〈余滴〉等の欄を設けました。

この欄へのご投稿内容は，医学に関連した随筆，先生の日常診療でご経験された興味ある症例，経験から得られた 診療の秘訣, 関係医師会における最新の話題, その他後輩に是非伝えたい医学的知見, 研究上の興味ある話題など広 く先生の身近な医学的事項についてご執筆願いたいと思います。〈プロムナード〉は図表等を含め, $2,100 〜 2,900$ 字 (刷上がり2頁), 〈診療ノート〉〈余滴〉等は300 800字, 原稿締切日の限定はありませんが, 編集会議開催日の毎月 第 3 又は第 4 木曜日迄に到着するようご配虑下さい.

なお，特集主題についても会員各位のご意見・ご希望を編集室宛におよせ下さい.

『順天堂医学』は広く，医学界の新知識を紹介することを基本方針とし，毎号特集形式で編集する．その原稿は 編集委員会から執筆者に依頼する。このほかに原著論文等も掲載するが，掲載希望者は上記の投稿規程を守って戴 きたい．依頼原稿（医学プロムナードを含む）に対しては別に規定する原稿料を呈する．原著など投稿原稿につい ては，規程の掲載料を徵収する。 